\title{
Die invloedsverlies van die kerk as geloofsgemeenskap op Christen adolessente se besluite rondom seksualiteit
}

\author{
Author: \\ Mathys J. Bornman ${ }^{1}$ \\ Affiliation: \\ ${ }^{1}$ School of Biblical \\ Counselling and Church \\ Ministry, Faculty of Theology, \\ North-West University, \\ Potchefstroom Campus, \\ South Africa \\ Correspondence to: \\ Mathys Bornman \\ Email: \\ mathys.bornman@nwu.ac.za \\ Postal address: \\ PO Box 147, Faculty of \\ Theology, North-West \\ University, Private Bag \\ X6001, Potchefstroom 2520 , \\ South Africa \\ Dates: \\ Received: 21 Oct. 2011 \\ Accepted: 08 May 2012 \\ Published: 13 Mar. 2013 \\ How to cite this article: \\ Bornman, M.J., 2013, 'Die \\ invloedsverlies van die kerk \\ as geloofsgemeenskap op \\ Christen adolessente se \\ besluite rondom seksualiteit', \\ In die Skriflig/In Luce Verbi \\ 47(1), Art. \#95, 9 pages. \\ http://dx.doi.org/10.4102/ \\ ids.v47i1.95

\section{Copyright:} \\ (C) 2013. The Authors. \\ Licensee: AOSIS \\ OpenJournals. This work \\ is licensed under the \\ Creative Commons \\ Attribution License.
}

Read online:
Baie Suid-Afrikaanse adolessente is seksueel aktief, ten spyte van wat hulle geloofsgemeenskap se lering oor seksuele aktiwiteite is. Daar kan nie 'n onderskeid gemaak word tussen die seksuele aktiwiteite van adolessente wat aan 'n geloofsgemeenskap behoort en adolessente wat nie aan 'n geloofsgemeenskap behoort nie. Hierdie studie argumenteer dat die rede vir hierdie tendens die verlies aan invloed is wat die geloofsgemeenskap op die besluitnemingsraamwerk van adolessente het met betrekking tot seksuele aktiwiteite. Deur die gebruik van deelnemerobservasie-navorsing as metodologie het adolessente deelnemers aan hierdie studie die inligtingsbronne wat adolessente oor seksuele aktiwiteite gebruik, geïdentifiseer asook die boodskappe wat hierdie bronne deurgee. $\mathrm{Na}$ aanleiding van hierdie data, binne die konteks van reeds bestaande literatuur, word die afleiding gemaak dat die kerk, as 'n geloofsgemeenskap, nie meer 'n invloed het op adolessente se seksuele aktiwiteite en hulle besluite daarrondom nie. Hierdie bevindings word binne die konteks van adolessensie as ontwikkelingsfase asook die ontwikkeling van moraliteit geplaas.

The loss of influence of the faith community on Christian adolescents regarding decisions of sexual activities. Many South African adolescents are sexually active, regardless of what their faith communities teach on sexual activity. No distinction can be made between the sexual activities of adolescents who belong to a faith community and adolescents without one. This study argues that this trend prevails because the faith community no longer has an influence on the decision-making framework of adolescents. By using participant observation research as methodology the adolescent participants in this study identified the sources of information about sexual activities that are used by adolescents and also the messages from these sources. Following this argument, within the context of existing literature, the argument is that the church, as community of faith, has no longer an influence on adolescents' sexual activities and their decisions regarding sex. These findings are placed within the context of adolescence as a developmental phase and the development of morality during this phase.

\section{Inleiding}

Suid-Afrikaanse adolessente is seksueel aktief, ten spyte van hulle geloofsgemeenskappe se siening oor seksuele aktiwiteite, of die geloofsgemeenskappe se onderrig oor seks. Adolessente deelnemers aan 'n studie van Mash (2006:43) was deeglik bewus van hulle geloofsgemeenskap (kerk) se verbod op voorhuwelikse seksuele aktiwiteite, maar die studie kon geen verskil tussen die seksuele aktiwiteite van adolessente binne die spesifieke Christelike geloofsgemeenskap en adolessente buite die geloofsgemeenskap vind nie (Mash 2006:59).

\section{Agtergrond}

Gelowige adolessente wat betrokke is by of aan seksuele aktiwiteite deelneem, is nie 'n verskynsel wat uniek is tot Suid-Afrika nie. Meier (2003:1032) het in 'n studie onder Amerikaanse adolessente gevind dat geloofsoortuiging wel ' $n$ invloed het op die betrokkenheid van adolessente by seksuele aktiwiteite, maar dat seksuele aktiwiteite terselfdertyd ook 'n negatiewe invloed het op die betrokkenheid by geloofspraktyke en geloofsoortuiging. Hierdie tendens is ook in 'n studie in Botswana waargeneem. Deelnemers aan hierdie studie (Orapeleng 2002:11) het getoon dat 'n groot aantal van die kerkjeug seksueel aktief is, alhoewel seksuele aktiwiteite voor die huwelik teen die lering van hulle geloofsgemeenskap is.

Verdere studie in die VSA (Hardy \& Raffaelli 2003:737) sowel as in Nigerië (Odimegwu 2003:137) het gevind dat alhoewel geloofsoortuiging 'n negatiewe effek op seksuele aktiwiteite by adolessente veroorsaak deurdat dit deelname aan seksuele aktiwiteite verminder, daar nie bewys gelewer kan word dat geloofsoortuiging wel seksuele aktiwiteite voorkom nie. Verhoogde betrokkenheid by geloofspraktyke het wel 'n invloed gehad op die latere inisiëring van seksuele aktiwiteite 
onder adolessente. Sekere aspekte van geloofsoortuiging, spesifiek die siening aangaande voorhuwelikse seksuele aktiwiteite, het ook ' $n$ invloed op die houdings teenoor en die betrokkenheid by seksuele aktiwiteite gehad (Odimegwu 2003:137).

Die betrokkenheid van adolessente by seksuele aktiwiteite ten spyte van die boodskap wat hulle geloofsgemeenskap verkondig, laat vrae ontstaan oor die invloed van geloofsoortuiging op die algehele moraliteit van adolessente. Buiten geloofsoortuiging is daar ook verskeie ander faktore wat die ontwikkeling van moraliteit by adolessente kan beïnvloed. Swart (2004:69) vind 'n verband tussen die 'lokus van kontrole' van die individu en die vlak van die individu se morele ontwikkeling. Coetzee (2002:2-4) identifiseer ook ander faktore wat 'n invloed het op die ontwikkeling en uitdrukking van moraliteit by adolessente, naamlik die omgewing waarin die adolessente hulle opvoeding ontvang, in ag genome die bevinding dat opvoeding en logiese denke direk met die vlak van morele redenering gekoppel kan word; die familie en tuisomgewing speel ' $n$ belangrike rol by die ontwikkeling van moraliteit by adolessente; persepsies van moraliteit sowel as die ontwikkeling van moraliteit verskil tussen kulture en tussen etniese groepe; en daar is 'n sterk ooreenkoms tussen geloof en moraliteit. Die frekwensie van geloofspraktyke het ' $n$ impak op die moraliteitsvlak van die individu. Daar is dus ' $n$ verband tussen moraliteit en geloofsoortuiging, aangesien geloof 'n direkte invloed op morele ontwikkeling asook op moraliteit het.

Geloofsoortuiging dien as die fondament vir en van moraliteit. Die Christelike geloofsoortuiging dien as fondament vir Christelike moraliteit (Prins 2001:105; Brill 1979:4; Wright 2003:72). Vir menige individu is die waardes wat deel van hulle geloofsoortuiging uitmaak die bron van morele besluitneming. Die lering van die spesifieke geloof het 'n invloed op individue se waardes asook op hulle besluite (Odimegwu 2003:126). Meier (2003:1032) en Mash (2006:44) het albei gevind dat geloofsoortuiging en die betrokkenheid by geloofspraktyke negatief beïnvloed word deur die betrokkenheid by seksuele aktiwiteite. Adolessente wat seksueel aktief is, het verlaagde moraliteitsvlakke sowel as geloofservaring en geloofsbetrokkenheid getoon, vergeleke met adolessente wat nie seksueel aktief was nie (Coetzee 2002:16; Mash 2006:44; Meier 2003:1032).

Menslike ontwikkeling tydens adolessensie, die konsep van moraliteit, die invloed van geloofsoortuiging op moraliteit, sowel as adolessente se seksualiteit word binne die konteks van hierdie artikel bespreek. Teen die agtergrond van die invloed wat geloofsoortuiging op adolessente se moraliteit en seksualiteit het, word deelnemerobservasie-navorsing gebruik om die spesifieke bronne vir gelowige adolessente se inligting oor seks en seksuele aktiwiteite, die boodskappe van hierdie bronne asook die boodskappe van die kerk as geloofsgemeenskap ten opsigte van adolessente se seksuele aktiwiteite te identifiseer. Hierdie bronne vorm deel van die faktore wat 'n invloed het op die ontwikkeling en funksionering van adolessente se moraliteit.
In aansluiting by reeds bestaande literatuur, word die kerk vervolgens as rolspeler in die seksuele lewens van gelowige adolessente binne die Suid-Afrikaanse konteks bespreek. Terselfdertyd word gelowige adolessente se behoeftes ten opsigte van hulle geloofsgemeenskap se hantering van adolessente seksualiteit gekommunikeer. Die artikel fokus spesifiek op die geloofsgemeenskap se boodskap oor seks in teenstelling met die sterker boodskap van ander bronne wat 'n invloed het op die besluitnemingsraamwerk van adolessente met betrekking tot seksuele aktiwiteite.

\section{Menslike ontwikkeling tydens adolessensie}

By die mens is adolessensie 'n tydperk van kognitiewe en fisiese groei wat tussen die ouderdomme van 12 en 19 jaar plaasvind. Hierdie ontwikkelingstydperk word deur verskeie fisiese veranderings gekenmerk waarvan seksuele rypwording of seksuele ontwikkeling die opvallendste kenmerk is. Seksuele ontwikkeling val saam met 'n verskeidenheid fisiese veranderings wat in die liggaam van die adolessent plaasvind. Hierdie ontwikkelingsfase word ook deur vinnige fisiese ontwikkeling gekenmerk wat van individu tot individu kan verskil, omdat daar 'n groot verskeidenheid invloede op die fisieke ontwikkeling van adolessente inwerk soos gene, die omgewing, hormoonvlakke, algemene gesondheid en dieet (Greathead, Devenish \& Funnell 2008:3).

By albei geslagte vind interne en eksterne verandering plaas soos die skielike groei van ledemate en 'n toename in liggaamshare asook die voorkoms van sweet, die vergroting van die heupe en die ontwikkeling van borste by meisies. Soortgelyke eksterne verandering vind ook by seuns plaas, asook 'n verandering in die stemtoon (Greathead et al. 2008:4; Louw, Van Ede \& Louw 1998:392).

Interne veranderings, veral van die geslagsorgane, vind ook plaas. By seuns vergroot die testes en word testosteroon geproduseer. Testosteroon is verantwoordelik vir gelaatstrekke wat met 'n manlike volwassene geassosieer word asook die produksie van semen. By meisies is dit nie alleenlik die borsweefsel wat ontwikkel en vergroot nie, maar die voortplantingsorgane soos die Fallopiusbuise en die uterus bereik ook seksuele volwassenheid en ovulasie en menstruasie begin gedurende hierdie ontwikkelingsfase (Greathead et al. 2008:20). Hierdie ontwikkeling het tot gevolg dat die adolessent seksuele gevoelens ervaar wat ook 'n impak op die kognitiewe en emosionele aspekte van die individu het (Greathead et al. 2008:15).

Bogenoemde veranderings vind plaas gedurende ' $n$ uiters belangrike tydperk in die mens se ontwikkeling, omdat dit saamval met die ontwikkeling van 'n persoonlike morele waardestelsel. Die ontwikkeling van 'n persoonlike waardestelsel bied riglyne vir adolessente se gedrag en help hulle om sosiaal en moreel verantwoordelike gedrag te openbaar (Louw et al. 1998:392). Die feit dat hierdie twee ontwikkelingsfases gelyktydig plaasvind, noodsaak dat die 
fisieke ontwikkeling van adolessente in verhouding met hulle morele ontwikkeling geplaas moet word. Dit het ook'n invloed op die ontwikkeling van die adolessent se persoonlikheid asook die ontwikkeling van sosiale verhoudings, wat veral romantiese en portuurgroepverhoudings insluit.

\section{Moraliteit}

Behalwe die fisiese veranderings wat tydens die adolessente ontwikkelingsfase plaasvind, vind ook kognitiewe veranderings plaas, wat wel minder opvallend is en binne die kulturele konteks 'n groter verskeidenheid vertoon as die normale fisiese ontwikkeling (Louw et al. 1998:417). Hierdie veranderings is sigbaar in die emosionele verandering wat adolessente ondergaan, asook hulle vermoë tot formeel-operasionele denke. Adolessente kan in hierdie fase as egosentries beskou word, omdat hulle nie die fokus van hulleself af kan verskuif nie. Die veranderings in die kognitiewe vermoëns het gevolglik 'n impak op adolessente se reeds bestaande verhoudings asook die verhoudings (romanties of portuurgroep) wat nog kan volg. Louw et al. (1998:464) noem dat adolessente tydens hierdie fase van kognitiewe ontwikkeling ook die grondslag van 'n persoonlike waardestelsel ontwikkel, wat riglyne vir hulle gedrag bied. Dit staan bekend as die morele ontwikkeling of die ontwikkeling van moraliteit van die adolessent.

Moraliteit behels nie net die individu se morele besluite nie, maar ook die morele gedrag wat deur die individu geopenbaar word. Hierdie argument is op Price Tangney (2003:385-386) se verduideliking van moraliteit gebaseer. Hy bepaal dat moraliteit uit drie verskillende aspekte bestaan.

Eerstens, argumenteer Price Tangney (2003:385), bestaan moraliteit uit die individu se eie morele standaarde. Hierdie morele standaarde word deur die individu se kulturele konteks bepaal en hou verband met die morele waardes wat in die spesifieke kultuur aanvaar word. Dit is in ooreenstemming met Larney en Lotter (2005:663) se bevinding dat etiese en morele waardes verstaan kan word as die riglyne waarvolgens individue verantwoordbare en sosiaal-aanvaarbare besluite neem.

Die tweede aspek wat morele besluite en morele gedrag beïnvloed, is die proses van morele beredenering wat die individu ondergaan (Price Tangney 2003:385). Hierdie proses is eksklusief kognitief en individuele verskille word deur die individu se morele ontwikkeling bepaal soos uiteengesit deur Kohlberg (1976). Singer (1999:155) voer aan dat die belangrike van die kognitiewe ontwikkeling van moraliteit geleë is in die idee dat moraliteit in die geheel, maar veral ook morele beredenering, primêre funksies van die intellek is en dat dit beskryf kan word as die beredenering in 'n soeke na regverdigheid.

Die derde aspek van moraliteit is affek. Price Tangney omskryf morele affeksie as die motivering agter die individu se behoefte om eerder die regte besluite te neem as die verkeerde (Price Tangney 2003:386). Prins (2001:105) beskryf hierdie verskynsel as die individu of gemeenskap se vermoë om tussen goed en kwaad te onderskei en daarvolgens op te tree. 'n Deel van morele affeksie kan, volgens Singer (1999:156), ook die fokus op verhoudings met ander individue wees en die empatie wat teenoor ander individue betoon word. Die emosies wat deur die betrokke partye by die individu aangewakker word, het dus ook 'n invloed op die morele besluit.

Volgens hierdie argument bestaan individuele moraliteit uit die individu se morele standaarde, morele beredenering en morele affeksie. Hierdie drie is saam verantwoordelik vir die individu se morele besluite wat tot morele gedrag lei (Price Tangney 2003:385).

Moraliteit as deel van die ontwikkeling van adolessente word deur Kohlberg (1976) en deels ook deur Piaget (aangehaal in Slavin 2006:51) as 'n kognitiewe morele ontwikkeling beskryf. Piaget (1971) redeneer dat die kognitiewe ontwikkeling van ' $n$ individu die resultaat is van die interaksie van die individu met die omgewing. Op grond hiervan oordeel Piaget dat die mens se kognitiewe ontwikkeling in vier verskillende periodes plaasvind, waarvan die 'formeel-operasionele periode' tydens adolessensie geskied (Louw et al. 1998:77). Tydens hierdie periode ontwikkel adolessente die vermoë om sowel logies as abstrak te dink en hulle kan deduktief (van die algemene na die spesifieke) en induktief (van die spesifieke na die algemene) redeneer. Die belangrikste kenmerk van formeel-operasionele denke is dat dit nie aan konkrete voorwerpe gebonde is nie, maar dit kan ook abstrakte dinge soos moontlikhede en hipoteses hanteer. Dit beteken dat adolessente kan dink of redeneer ooreenkomstig dit wat kan of mag wees - iets wat volgens Piaget nie in die voorafgaande periodes moontlik is nie (Louw et al. 1998:82).

Aansluitend hierby bepaal Kohlberg (1976:34-35) dat die morele ontwikkeling op drie vlakke plaasvind, elkeen bestaande uit twee stadia. Die eerste moraliteitsvlak, 'prekonvensionele moraliteit', word alreeds gedurende die kinderjare bereik ten spyte van individuele verskille. 'Vlak II, konvensionele moraliteit' word deur die meeste adolessente en volwassenes bereik, maar min volwassenes bereik 'Vlak III: post-konvensionele moraliteit'.

Op 'Vlak II, konvensionele moraliteit' konformeer die individu met die sosiale orde en die verwagtings van ander mense. Die implikasies hiervan is dat die individu se morele standaarde ekstern beheer word. Dit beteken dat, ten spyte van die onmiddellike gevolge, die individu met die morele verwagtings van ouers, portuurgroepe en ander sosiale groepe, wat die individu se geloofsgemeenskap insluit, sal konformeer (Louw et al. 1998:466). Kohlberg (1976:32) noem ook dat 'n individu op hierdie vlak die self geïdentifiseer het en dat die reëls en verwagtings van ander, veral gesagsfigure, geïnternaliseer is (Kohlberg 1976:33).

Hierdie verduideliking van adolessente se moraliteit word ook deur Swart (2004:68) bevestig. Hy bevind dat adolessente op hierdie vlak hulle eie morele perspektief verander om met 
persoonlike verwagtings asook die sosiale orde te konformeer ten opsigte van groepsdruk en persepsies in die media. Die spesifieke wyse waarop moraliteit en die besluite wat daarmee geassosieer en in die lewens van adolessente gevind word, gee Berkowitz (2005:77) aan as die rede waarom tieners nie die gevolge verstaan van die besluite wat hulle neem nie. Saelen en Markovits (2008:54) voer ook aan dat morele keuses uiteraard kompleks is en dat die verstaan daarvan van verskeie faktore afhang. In situasies waar morele keuses gemaak word, hang individue se gedrag af van hulle kennis aangaande ' $n$ groot verskeidenheid kognitiewe, sosiale en morele sisteme.

Met die fisiese ontwikkeling van adolessente en die konsep van moraliteit binne hierdie ontwikkelingsfase in gedagte, volg die bespreking van die invloed van geloofsoortuiging as bron van morele standaarde op die ontwikkeling van moraliteit by adolessente. Die invloed van geloofsoortuiging (as deel van moraliteit) op adolessente se seksualiteit word ook bespreek.

\section{Die invloed van geloofsoortuiging op adolessente se moraliteit}

Dit is onmoontlik om die invloed van geloofsoortuiging op moraliteit te ontken. Augustinus (354-430 n.C; aangehaal in Vorster 2004) het gesê dat die mens nie morele besluite onafhanklik van sy geloofsoortuiging kan neem nie. In dieselfde bron verwys Vorster (2004:70-71) verder na Augustinus se argument in sy ponering dat die absolute goed en die geskape mens se bestaan en goedheid alleen in die goedheid van God gevind word. Augustinus grond hierdie siening op die persepsie dat die goed in die mens slegs goed kan wees indien die mens se lewe deur sy afhanklikheid van God en sy verhouding met God bepaal word. Augustinus is dus van mening dat die motivering vir morele gedrag die soeke na geluk is en dat hierdie soeke afhanklik is van die individu se soeke na God. Mense se geloofsoortuigings bepaal dus die gedrag wat hulle openbaar.

Binne die gereformeerde tradisie as geloofsoortuiging word die bydrae van Calvyn hoog geag. Vorster (2004:74) voer aan dat Calvyn benadruk dat God se soewereiniteit die sentrale gedagte agter alles moet wees. Hiervolgens word die mens se gedrag bepaal deur die sigbaarmaking van God se glorie in die gedrag van die mens. Calvyn lê klem op heiligmaking wat die resultaat is van God se werk in die mens deur sy Gees. Die Gees laat God se glorie in die mens sigbaar word. Die mens moet dus 'n lewe van dankbaarheid op alle vlakke van die samelewing openbaar, ook in sy morele uitlewing. Calvyn redeneer ook vanuit die oogpunt van imago Dei, die feit dat die mens na die beeld van God geskape is. Die wete dat die mens 'in dieselfde beeld as God' geskape is, moet in die gedrag van die individu voortleef om nie afbreuk aan God se beeld te doen nie, maar ook om die morele karakter van God se beeld aan die wêreld te toon (Vorster 2004:76).

Brill (1979:3) is van mening dat die vraag na reg en verkeerd 'n universele deel van geloofsoortuiging is. Geloofsoortuiging is 'n komplekse verskynsel en bestaan uit meer as bloot die individu se moraliteit; dit sluit altyd moraliteit op die een of ander vlak in. Geloof veronderstel dat die morele lewe wat deur die geloofsoortuiging voorgehou word, deel van die individu se morele welstand uitmaak. Om in ooreenstemming met die voorgestelde moraliteit van die geloofsoortuiging (in hierdie artikel: die Christelike geloofsoortuiging) te leef, verskaf aan die individu bevrediging en totale geluk (Brill 1979:4). Die individu se geloofsoortuiging moet dus 'n invloed hê op die moraliteit wat die individu openbaar.

'n Latere studie van Coetzee (2002:4) vind 'n sterk ooreenkoms tussen die betrokkenheid van die individu by 'n geloofsoortuiging (met die gepaardgaande aktiwiteite en verantwoordelikhede) en moraliteit. Die frekwensie van aktiwiteite wat met geloofsoortuiging geassosieer is, het 'n direkte invloed op die vlak van moraliteit getoon, asook die uitlewing daarvan. Coetzee (2002:15) is van mening dat geloofsoortuiging ' $n$ direkte invloed op morele ontwikkeling het.

Hierdie bevinding stem ooreen met dié van Odimegwu (2005:126) wat bevind dat die geloofswaarde, soos geïmpliseer deur die geloofsoortuiging, die primêre bron van morele standaarde is. Juis hierom sal die leer van die kerk 'n groot rol speel in die vorming van individuele houdings, waardes en besluite. Die mate waarin hierdie leer egter die besluite van die individu beïnvloed, hang af van die toewydingsvlak wat die individu aan die geloofsoortuiging verleen.

Ongelukkig is bywoning van geloofsaktiwiteite en die invloed van geloofsoortuiging op die moraliteit van die individu nie wedersyds van mekaar afhanklik nie. Alhoewel Suid-Afrika as 'n sekulêre land beskou kan word, is die deelname aan geloofspraktyke onder Suid-Afrikaanse burgers hoog: 75\% van Suid-Afrikaners erken geloofsbetrokkenheid, waarvan $82 \%$ oorwegend Christelik van aard is. Verder is die kerk, naas sport, 'n gewilde sosiale verband waarmee SuidAfrikaanse jeug assosieer (Cooksey \& Dooms 2009:2). Hierdie statistiek lig egter net die potensiële invloed uit wat die kerk en die gepaardgaande geloofsoortuiging op adolessente kan hê en dit is nie ' $n$ weerspieëling van die ware invloed nie. Die invloed van geloofsoortuiging op riskante gedrag, veral riskante seksuele gedrag, word vervolgens bespreek.

\section{Die invloed van geloofsoortuiging op adolessente se seksualiteit}

Geloofsoortuiging is 'n komplekse konstruksie wat twee vorms van betrokkenheid behels, naamlik private en openbare betrokkenheid. Studie het getoon dat adolessente wat by aktiwiteite betrokke is wat met godsdiens geassosieer word soos die bywoning van kerkdienste, jeuggroepe, geloof in God en gereelde gebed, minder geneig is om aan gedrag deel te neem wat sleg is vir hulle gesondheid (Francis 2007:16). Hoë vlakke van betrokkenheid by geloofsoortuigingsaktiwiteite word met die vertraging van die seksuele debuut geassosieer (Goggin et al. 2007:125; Hardie \& Raefaelli 2003:723; Odimegwu 2003:127; Simons, Burt \& Peterson 2009:468). 
Hierdie verskynsel word nog duideliker waargeneem by adolessente wat by geloofspraktyke betrokke is en ' $n$ eed van maagdelikheid aflê. So 'n eed bepaal dat die adolessente belowe om hulle individuele maagdelikheid te behou tot hulle in die huwelik tree (Francis 2007:17).

Ten spyte van talle studies wat gevind het dat geloofsoortuiging ' $n$ invloed op die seksuele aktiwiteite van adolessente toon (Francis 2007:16; Goggin et al. 2007:125; Hardy \& Rafaelli 2003:732; Meier 2003:1032), het Mash (2006:43) in 'n studie onder die Suid-Afrikaanse jeug gevind dat die seksuele aktiwiteite van adolessente binne die kerk nie verskil van dié daarbuite nie. 'n Groot aantal jeugdiges binne die spesifieke geloofsoortuiging was aktief betrokke by verskeie vorms van seks en riskante seksuele gedrag, wat meer as een seksuele vennoot en met geringe gebruik van kontrasepsie ingesluit het.

Hierdie verskynsel kan egter verduidelik word aan die hand van die gevolgtrekkings van Odimegwu (2003:126). Hy bevind dat ten spyte daarvan dat sekere geloofsoortuigings voorhuwelikse seks afraai, die vlak van toewyding wat die individu aan die geloofsoortuiging heg, 'n sterker bepaling het op die individu se houding teenoor voorhuwelikse seks. Die blote affiliasie met die geloofsoortuiging dra nie genoegsame motivering om nie by voorhuwelikse seks betrokke te raak nie (Odimegwu 2003:126). Hierdie bevinding sluit aan by die siening van Simons et al. (2009:467) asook Francis (2007:24) wat gevind het dat adolessente wat 'n meer fundamentalistiese en konserwatiewe geloofsoortuiging aanhang, minder seksueel aktief is, minder seksuele vennote het en minder situasies identifiseer waarbinne seksuele gedrag aanvaarbaar is. Goggin et al. (2007:135) voer ook aan dat adolessente minder godsdienstig raak namate hulle ouer word. Dit speel ook 'n rol in die adolessent se betrokkenheid by seksuele aktiwiteite.

As een van die grootste geloofsoortuigings in die wêreld, ondersteun die Christelike geloofsoortuiging in die meeste van sy variante seksuele onthouding voor die huwelik (vgl. 1 Kor 6). Die heiligheid van die liggaamlike intimiteit en die instelling van die huwelik wat vir God aanvaarbaar is, word as die Christelike ideaal voorgehou (Cooksey \& Dooms 2009:1).

Die onthouding van seks voor die huwelik word as ' $n$ beginsel vir 'n Christelike lewe en 'n Christelike moraliteit voorgehou. Tog, volgens Winner (2005:29), moet die meeste Christene hierdie 'onthouding' aanleer juis weens die sterk klem wat die sekulêre omgewing op seks plaas. Dit bring mee dat Christelike gemeenskappe deel is van die seksuele revolusie met die noodgedwonge implikasie dat voorhuwelikse seks ook binne Christelike gemeenskappe plaasvind. Die geloofsoortuigings het egter nie meer ' $n$ invloed op die seksuele aktiwiteite van adolessente nie, omdat die plek van die geloofsoortuiging van die individu nie meer relevant is nie (Cooksey \& Dooms 2009:8).

Met die invloed van geloofsoortuiging op adolessente se moraliteit en seksualiteit in gedagte, word die metodologie van Deelnemerobservasie vervolgens bespreek.

\section{Deelnemerobservasie as metodologie}

Deelnemerobservasie as 'n navorsingsmetodologie kom algemeen in die sosiale wetenskappe voor en word dikwels met sosiale transformasie geassosieer (Denzin \& Lincoln 2008:273). Deelnemerobservasie-navorsing maak gebruik van 'n sistematiese opname van gedrag wat deur die observeerder (in hierdie geval die navorser self) binne 'n natuurlike situasie waargeneem (geobserveer) word. Observasie alleen dui nie vir die navorser aan wat die selfpersepsie van die deelnemers is nie, maar dit kan maklik gebruik word om onbewuste gedrag van die deelnemers te openbaar (Gorman \& Clayton 2005:41). Kemp (2001:528) sluit hierby aan wanneer hy noem dat deelnemerobservasie 'n geleentheid skep om dít wat mense doen in plaas van dít wat hulle sê hulle doen, te bestudeer. Dit impliseer dat die rolle wat deur die deelnemers en die observeerder vertolk word, uiters belangrik is in 'n studie waar deelnemerobservasie gebruik word.

Deur die analise en interpretasie van hierdie observasies, is dit moontlik om kollektief deur middel van die navorser en die deelnemers, kennis te genereer wat kan lei tot die bereiking van doelwitte wat vooraf deur die groep deelnemers geïdentifiseer is (Collins 1999:2). Hierdeur voldoen die navorsing aan die definisie van Jason et al. (2004:4) wat deelnemerobservasie as 'n breë term gebruik om 'n verskeidenheid metodes te beskryf wat die gemeenskap, wat deel vorm van die navorsing, te versterk.

'n Eie definisie van deelnemerobservasie is dat deelnemerobservasie gebruik maak van 'n spesifieke groep binne 'n gemeenskap wie se gedrag in 'n natuurlike situasie, deur 'n navorser geobserveer en aangeteken word. Die navorser moet vertroud wees met die leefwêreld van die deelnemers. Hierna kan die navorser en die deelnemers die observasies interpreteer om sodoende die doelwitte van die studie of navorsing te bereik en om aan die gemeenskap 'n dieper insig in hulle eie gedrag te gee.

Weens die sensitiewe aard van die saak wat ondersoek word, is deeglike besinning nodig voordat op 'n bepaalde metodologie besluit word. Vir die doeleindes van hierdie studie het die navorser op deelnemerobservasie besluit op grond van die verduideliking deur Gorman en Clayton (2005:95) dat deelnemerobservasie onder andere gebruik kan word vir 'n verkennende studie waarin 'n moeilik verklaarbare verskynsel bestudeer word, maar ook vir 'n verklarende studie waarin die oorsake van 'n spesifieke verskynsel wat bestudeer word, verduidelik word. Dit sluit verder aan by die verduideliking van Robson (2002:315) dat deelnemerobservasie gebruik kan word in situasies waar daar klein groepe is, aangesien die navorser alle betrokkenes by die studie moet ken, iets wat kwalik moontlik is met groter groepe.

Die doel van hierdie metodologie is om kennis, insig en bewustheid oor seksuele aktiwiteit onder adolessente aan die 
navorser sowel as die gemeenskap te verskaf. Gepaard gaande hiermee word die navorser en die gemeenskap bemagtig op 'n vlak waar 'n bewustheid van seksuele aktiwiteite onder adolessente die onderliggende besluitnemingsraamwerk van adolessente openbaar (Reason 1998:269).

In hierdie navorsing is gebruik gemaak van 'n spesifieke deelnemerobservasie-navorsingsintrument, naamlik die Participatory Inquiry into Religion and the Sexual Health of Young People (PIRASH). Hierdie navorsingsinstrument maak deel uit van 'n werkswinkel wat deur die African Religious Health Assessment Programme (ARHAP) ontwerp is met die doel om die verhouding tussen adolessente se seksuele aktiwiteite, hulle gesondheid en geloof te bestudeer. Hierdie instrument het gebruik gemaak van aktiwiteite waarin sekere vrae aan adolessente gestel word en reaksies van hulle verwag is. Die antwoorde en gedrag word deur die navorser geobserveer en geïnterpreteer en intyds aan die adolessente deelnemers gekommunikeer. Die adolessente wat aan hierdie studie deelgeneem het, was tussen 16 en 18 jaar oud en $60 \%$ was vroulike en $40 \%$ manlike adolessente.

Die doel van hierdie navorsingsaktiwiteite was om adolessente se inligtingsbronne aangaande seks te identifiseer en te bespreek sowel as om die boodskappe wat adolessente van hierdie bronne ontvang, te identifiseer en te bespreek. Elkeen van hierdie navorsingsaktiwiteite het met 'n reflektiewe gesprek tussen die deelnemers en die observeerder afgesluit om die belang van die resultate wat gevind is met hulle te bespreek.

\section{Resultate}

\section{Adolessente se inligtingsbronne oor seks}

Die eerste deel van hierdie navorsing het vereis dat elke deelnemer die drie invloedrykste inligtingsbronne oor seks vir adolessente identifiseer. Met die weglating van duplikate, was die resultate die televisie, die skool, vriende, die kerk, VIGS-praatjies, die huis, die Internet, rekenaarspeletjies en tydskrifte. Hieruit kan afgelei word dat die media, bestaande uit die televisie, die Internet, rekenaarspeletjies en tydskrifte, die inligtingsbron oor seks is wat adolessente bedien. Interpersoonlike bronne soos vriende, wat ook die portuurgroep kan wees, en die huis, wat ouers en grootouers insluit, dien egter ook as inligtingsbronne. Die skool, veral vakke wat seksuele opvoeding behels en gefasiliteerde VIGS-praatjies dien ook as seksuele opvoeding. Laastens was daar ook adolessente wat gemeen het dat hulle kerk of geloofsgemeenskap as 'n bron van seksuele inligting dien.

In die tweede deel van hierdie navorsing het die deelnemers uit die vooraf-geïdentifiseerde bronne die twee belangrikste bronne geïdentifiseer. Die belang van die media (voorgestel deur die Internet sowel as die televisie) as inligtingsbron was duidelik, deurdat die media as die belangrikste inligtingsbron oor seks vir adolessente aangedui is. Van die totale groep deelnemers het $50 \%$ die media as die belangrikste inligtingsbron oor seks gesien. Vriende en die skool is deur $20 \%$ van die deelnemers as belangrik geag en die huis slegs deur $10 \%$. In hierdie deel van die ondersoek was die kerk as inligtingsbron heeltemal afwesig.

Die bevindings van ander navorsing met soortgelyke doelwitte is telkens in ooreenstemming gevind met die inligtingsbronne wat in hierdie studie geïdentifiseer is. Hetsroni (2008:14), Epstein en Ward (2008:113) en Pattee (2006:30) het soortgelyke resultate gevind, wat die rapportering van adolessente se inligtingsbronne om inligting oor seks in te samel, in ooreenstemming bring met huidige tendense.

Uit die reflektiewe gesprek, wat die derde en laaste deel van hierdie navorsingsaktiwiteit was, het dit duidelik na vore gekom dat adolessente nie op hulle gemak is om die kerk as 'n inligtingsbron oor seks te identifiseer nie, juis as gevolg van die boodskap wat die kerk oor seks aan adolessente deurgee. Daarbenewens vrees adolessente die openbaarmaking van hulle soeke na seksuele inligting.

Adolessente wat aan hierdie studie deelgeneem het, het tydens 'n ander aktiwiteit, waar die doel was om gesonde seksuele lewens van adolessente te identifiseer, aangetoon dat daar wel ' $n$ behoefte is vir meer toeganklikheid tot hulle geloofsleiers vir hulle vrae oor seks of seksuele aktiwiteite (Bornman 2011:74). Hierdie toeganklikheid word egter deur persoonlike gesprekke met spesifieke geloofsleiers binne die geloofsgemeenskap gekenmerk. Die geloofsgemeenskap (kerk) word nie as bron gebruik nie, maar wel die geloofsleiers. Hierdie verskynsel is ook deur Steyn en Lotter (2006:540) onder jong pasgetroude paartjies waargeneem.

Verder het dit ook duidelik geword dat die bruikbaarste en die mees gebruikte bron vir hierdie deelnemers die media was, spesifiek die Internet. Hierdie tendens is ook deur 'n literatuurstudie bevestig.

Vervolgens word die boodskap van die verskillende bronne ten opsigte van seks gegee en bespreek.

\section{Die verskillende bronne se boodskap oor seks}

$\mathrm{Na}$ aanleiding van die inligtingsbronne wat in die voorafgaande aktiwiteit deur die deelnemers aan hierdie studie geïdentifiseer is, het die volgende aktiwiteit op die boodskappe gefokus wat hierdie bronne aan adolessente aangaande seksualiteit, seksuele gedrag en seksuele aktiwiteite oordra. Hierdie aktiwiteit het dus drie dele gehad. Eerstens is die algemene boodskappe genoem van die bronne wat in die voorafgaande aktiwiteit geïdentifiseer is. Daarna is spesifiek gefokus op die algemene boodskappe oor seks wat uit die adolessente se geloofsgemeenskappe kom en watter boodskappe adolessente as die belangrikste ag. Die navorsingsaktiwiteit is met ' $n$ reflektiewe gesprek tussen die navorser en die deelnemers afgesluit.

Die deelnemers is versoek om vir elkeen van die bronne wat in die vorige aktiwiteit as belangrik geag is, die belangrikste boodskap neer te skryf wat die spesifieke bron 
oor seks gee. Die algemene boodskap van bronne soos die Internet, vriende, die skool, televisie en selfs die adolessent se huis, het seksuele aktiwiteite as positief gesien, of dit binne die raamwerk van verantwoordelikheid aangemoedig. Mediabronne soos die Internet en die televisie het 'n uiters positiewe prentjie oor seks geskets.

Die boodskappe van die huis en die skool, as bronne van inligting oor seks plaas nie noodwendig klem op seks as iets slegs nie, maar op die verantwoordelikheid wat op die adolessent rus om gesonde seksuele praktyke te beoefen. Die gebruik van kondome en ander vorms van kontrasepsie word aanbeveel om die gevaar van MIV en VIGS asook ongewenste swangerskappe te voorkom. Die reflektiewe gesprek aan die einde van hierdie aktiwiteit het egter aangetoon dat adolessente 'n groter vrees vir MIV en VIGS het as vir swangerskappe, waarskynlik omdat MIV enVIGS ongeneeslik is, terwyl daar verskeie maniere is om die langtermyn effek van 'n ongewenste swangerskap vry te spring.

In ooreenstemming hiermee kom die boodskap wat adolessente van vriende ontvang, daarop neer dat seks iets normaals onder adolessente is en dat seksuele aktiwiteit deel is van die aanvaardingsproses en nodig is om deur die portuurgroep aanvaar te word. Tog is daar ook tekens dat adolessente seks as iets spesiaals beskou, deurdat die deelnemers aan hierdie studie klem gelê het op die konsep van trouman of -vrou. Vriende handhaaf dus die mening dat seksuele aktiwiteite goed en reg is indien daar 'n vertrouensverhouding tussen die twee partye bestaan en indien die moontlikheid van 'n langtermynverhouding nie uitgesluit is nie.

Die tweede deel van hierdie aktiwiteit het op die boodskappe gefokus wat adolessente by hulle geloofsgemeenskappe oor seks kry. Deelnemers het agt verskillende boodskappe geïdentifiseer:

- Moenie 'n meisie in die steek laat as sy swanger is nie.

- Moenie 'n aborsie oorweeg nie.

- Behou jou maagdelikheid totdat jy wil swanger raak.

- Hou seks spesiaal.

- Daar word nie regtig 'n boodskap ontvang nie.

- 'n Man het nie respek vir sy meisie as hy aandring op seks voor die huwelik nie.

- Moenie egbreuk pleeg nie.

- Seks voor die huwelik is sleg.

$\mathrm{Al}$ agt hierdie boodskappe reflekteer die seksuele aktiwiteite van adolessente as negatief. Die boodskap wat adolessente in die algemeen oor seksuele aktiwiteit vanaf die geloofsgemeenskap ontvang, is dat dit sleg en verkeerd is en dat daar negatiewe gevolge is vir enige vorm van seksuele aktiwiteit. Dit is ook belangrik om op die feit te let dat sommige van die adolessente wat aan hierdie studie deelgeneem het, ervaar dat hulle Christelike geloofsgemeenskap nie werklik iets oor seks sê nie. Daar bestaan dus ook die ervaring onder adolessente dat, aangesien die geloofsgemeenskap nie met hulle oor seks praat nie, hulle ook nie die vrymoedigheid het om met die leiers of persone in die geloofsgemeenskap oor seks te praat nie.

Die bronne en hulle boodskappe wat in die eerste deel van hierdie aktiwiteit genoem is, is as gewilder onder adolessente ervaar as adolessente se geloofsgemeenskap en die boodskappe van sodanige geloofsgemeenskap.

Hierdie bevinding word ondersteun deur navorsing wat die invloed van die genoemde bronne op die seksuele lewe van adolessente ondersoek (Epstein \& Ward 2008:114; Bleakley et al. 2009:46; Hetsroni 2008:17; Cohen, Chen \& Fitzgerald 2008:463).

Epstein en Ward (2008:114) se bevinding is dat adolessente seuns meen, op die vraag na die seksuele onderwerpe wat deur hulle ouers (by die huis) met hulle bespreek word, dat dit die meeste gehandel het oor MIV en VIGS, die gebruik van kondome en seksueel-oordraagbare siektes. Onderwerpe wat gehandel het oor seksuele plesier (soos masturbasie) is van die onderwerpe wat die minste deur ouers met adolessente bespreek word. Die grootste gedeelte van die kommunikasie oor seks tussen ouers en adolessente handel oor die veiligheid van seksuele aktiwiteite en die gebruik van effektiewe kontrasepsie, terwyl die minste van hierdie boodskappe oor die positiewe aspekte van seksualiteit handel (Epstein \& Ward 2008:114).

Hierdie bevindings stem ooreen met dié van Bleakley et al. (2009:37) wat gevind het dat ouers meer oor seksueel-oordraagbare siektes en MIV praat en dat hulle morele lesse daarby probeer insluit, terwyl die adolessent seksuele norme eerder van hulle portuurgroep leer. Ouers, grootouers en geloofsleiers is geassosieer met meer negatiewe oortuigings aangaande seks, maar elke gesagsfiguur is met 'n ander negatiewe boodskap oor seks geassosieer. Gesprekke met ouers lei tot 'n verlaging in die inisiëring van seksuele aktiwiteite deur adolessente, terwyl 'n negatiewe houding teenoor seksuele aktiwiteite aan die kant van die ouers gekoppel kan word aan minder deelname van adolessente aan seksuele aktiwiteite (Berenson et al. 2006:274).

In teenstelling hiermee is die boodskappe wat van vriende ontvang word, veel meer positief en aanmoedigend teenoor seksuele aktiwiteite. Berenson et al. (2006:274) redeneer dat die verhouding tussen die portuurgroep se persepsies van seksualiteit en dié van die adolessent afhanklik is van mekaar. Adolessente sal by dieselfde riskante seksuele aktiwiteite betrokke raak indien hulle vermoed dat hulle vriende (portuurgroep) ook by sulke aktiwiteit betrokke is. Vriende het 'n positiewe boodskap oor seks en voer ook aan dat om seksueel aktief te wees, die aanvaarde norm is (Bleakley et al. 2009:46).

Tesame met die positiewe boodskappe oor seks wat van vriende verkry word, dra die media (Internet en televisie) ook by tot verder positiewe boodskappe oor seks. 'n Analise van populêre programme onder adolessente identifiseer dat 83\% 'n seksuele inhoud het (Epstein \& Ward 2008:114). 
Die sterkste boodskap hiervan is dat seks as 'n rekreasieaktiwiteit gebruik kan word en dat seks buite 'n verhouding goed kan wees. Dit onderbeklemtoon seksuele risiko's en verantwoordelikhede. Tydskrifte wat op mans gefokus is, lig die sentraliteit van seksualiteit en seksuele ondervinding uit as deel van manlikheid. Dikwels word goeie seks in tydskrifte uitgebeeld in terme van kwantiteit en 'n verskeidenheid heteroseksuele aktiwiteite (Epstein \& Ward 2008:115). Verdere studies het ook getoon dat die gereelde blootstelling aan genres met 'n hoë seksuele inhoud geassosieer word met ' $n$ groter aanvaarding van nie-verhoudingseks en die seksuele stereotipering van vroue as voorwerpe en mans as pleasers (Epstein \& Ward 2008:115).

Cohen et al. (2008:463) wys daarop dat die voorkoms van die seksuele inhoud in die media dikwels ' $n$ misleidende beeld van seks kommunikeer en dat die inhoud dikwels min inligting oor gesonde seksuele gedrag bevat, maar wel seksuele stereotipes beklemtoon. Die media beeld uit dat seksuele gedrag onder adolessente aanvaarbaar is en dat dit ' $n$ invloed het op adolessente se seksuele aktiwiteite. Die blootstelling aan hierdie inhoud word met adolessente se eie inisiasie in seksuele aktiwiteite geassosieer.

Hetsroni (2008:18) meen dat die media deurtrek is met seksuele boodskappe wat adolessente aan 'n verskeidendheid seksuele gedrag blootstel. Die algemene voorstelling van seksuele gedrag in die media is een van risikovrye gedrag en dit skep die idee dat seks altyd pret en risikovry is. Ten spyte daarvan dat adolessente bewus is van die diskrepansie tussen die boodskappe van die media en dié van ander bronne, is die media meer toeganklik en dra daardie boodskappe dus meer gewig as boodskappe van ander bronne. Verder neem die vertroue wat adolessente in die boodskappe van die media plaas toe, juis omdat die ander bronne se boodskappe veroordelend of afwesig is (Hetsroni 2008:18).

Binne hierdie konteks poog die geloofsgemeenskappe ook om boodskappe oor seksuele aktiwiteite te kommunikeer wat adolessente se lewens kan beïnvloed. Benewens die feit dat hierdie studie toon dat die geloofsgemeenskappe se boodskappe oor seksuele aktiwiteite altyd die negatiewe aard van seks beklemtoon, rapporteer adolessente dat die geloofsgemeenskappe nie veel oor seks sê nie.

Bleakley et al. (2009:43) het gevind dat adolessente wat hulle geestelike leiers as inligtingsbronne oor seks gebruik, aansienlik minder geglo het dat seks positiewe gevolge kan hê indien hulle geslagsomgang het met persone anders as hulle seksuele of romantiese vennote. Hiermee saam is ook gevind dat geloofsleiers minder genader word vir inligting oor seks.

Die reflektiewe gesprek van hierdie navorsing het uitgewys dat die boodskappe wat adolessente van geloofsgemeenskappe ontvang as nutteloos en onduidelik ervaar word. Een van die deelnemers aan hierdie studie het selfs aangetoon dat die enigste gesprek wat in haar geloofsgemeenskap oor seks plaasgevind het, van 'n metafoor gebruik gemaak het dat seks naamlik soos roomys is. Wanneer hulle dus deur roomys gekonfronteer word, moet hulle onthou dat dit sonde is om roomys buite die huwelik te eet. Die boodskappe van geloofsgemeenskappe oor seks, indien enige, is dus dat seks verkeerd en sonde is - terwyl navorsing toon dat adolessente 'n behoefte daaraan het om oor seks te praat (Pattee 2006:31).

Dit is duidelik dat adolessente se geloofsgemeenskappe nie werklik 'n impak op die seksuele gedrag van adolessente maak nie. Die geloofsgemeenskappe se boodskap word oorskadu deur die neutrale boodskap wat die skool en die huis aan adolessente gee, naamlik om seks met verantwoordelikheid te beoefen en ook die oorweldigende positiewe boodskap wat van die media en hulle vriende ontvang word.

\section{Slot}

Die feit dat die geloofsgemeenskap nie deur adolessente as 'n belangrike inligtingsbron oor seks aangetoon word nie, bewys dat dit ruimte laat vir ander bronne soos die media en portuurgroepe om die etiese besluitnemingsraamwerk van adolessente te beïnvloed. Wanneer die boodskappe van die ander geïdentifiseerde bronne (die skool en die huis) bygevoeg word, blyk dit dat die geloofsgemeenskap, in hierdie geval die kerk, nie net alleen staan met die boodskap dat seks voor die huwelik verkeerd is nie, maar ook dat dit min tot geen invloed het op die besluite wat adolessente neem aangaande seksuele aktiwiteit nie.

Dit verklaar waarom adolessente wat tot Christelike geloofsgemeenskappe behoort, steeds seksueel aktief is en waarom hierdie adolessente se seksuele gedrag nie veel verskil van dié van adolessente wat nie tot 'n geloofsgemeenskap behoort nie.

Die adolessente wat aan hierdie studie deelgeneem het, het dit onomwonde gestel dat hulle eie geloofsgemeenskap (kerk) nie 'n invloed op hulle besluitnemingsraamwerk het met betrekking tot seksuele aktiwiteit nie. Alhoewel die geloofsgemeenskap se morele standaarde erken word, gee die geloofsgemeenskap nie genoeg inligting aan adolessente oor seks en seksuele aktiwiteite nie. Die meer tradisionele geloofsgemeenskappe is dikwels skugter om met adolessente oor seks of seksuele aktiwiteite te praat. Die boodskap wat van geloofsgemeenskappe ontvang word, word beperk tot die feit dat seks slegs binne die huwelik mag plaasvind en dat seks slegs tussen 'n man en vrou mag plaasvind. Deelnemers het ook te kenne gegee dat die geloofsgemeenskap nie veel oor seks of seksuele aktiwiteite sê nie - 'n verskynsel wat in die tradisioneel gereformeerde sowel as die charismatiese geloofsgemeenskappe voorgekom het. Die boodskap van die geloofsgemeenskap verskil grootliks van die boodskappe van ander bronne wat adolessente raadpleeg vir inligting oor seks. Die geloofsgemeenskap se boodskap word ook aansienlik minder belangrik geag as dié van ander bronne.

Die besluitnemingsraamwerk van die deelnemers aan hierdie studie het nie dieselfde standaarde as dié van hulle Christelike gemeenskappe getoon nie, maar meer 
ooreengestem met die besluitnemingsraamwerk van adolessente wat nie aan geloofsgemeenskappe behoort nie en wie se besluite beïnvloed word deur bronne soos die media, portuurgroepe, seksuele opvoedingsprogramme by skole en die boodskappe wat hulle tuis ontvang.

Die gevolgtrekking is dus dat, ten spyte van hulle geloofsgemeenskap se boodskappe oor seks, Christelike adolessente dieselfde morele standaarde met betrekking tot seksuele aktiwiteite het as ander adolessente wat nie aan 'n geloofsgemeenskap behoort nie. Na aanleiding van die resultate van hierdie studie kan dit aangevoer word dat die kerk as geloofsgemeenskap nie 'n invloed het op die adolessente lidmate se morele standaarde nie - veral nie ten opsigte van seksuele aktiwiteite nie.

Die resultate in hierdie studie kan gebruik word om geloofsgemeenskappe (kerke) aan te spoor om meer openhartig oor seksuele aktiwiteite met adolessente te wees. Adolessente wat reeds seksueel aktief is, het te kenne gegee dat hulle nie hulle eie geloofsgemeenskap kan nader oor hulle seksuele aktiwiteite nie. Die geloofsgemeenskap word dus ' $n$ struikelblok vir adolessente in hulle strewe na 'n gesonde seksuele leefstyl, omdat die geloofsgemeenskap nie 'n rol speel in hulle seksuele lewe nie. Op grond van hierdie verskynsel word aanbeveel dat geloofsgemeenskappe, spesifiek die Christelike kerk, dringend aandag gee aan die ontwikkeling en toepassing van programme waarin die geloofsgemeenskap se waardes en norme insake seksuele aktiwiteit duidelik aan adolessente gekommunikeer word. Die geloofsgemeenskap moet ook bewus word van die seksuele aktiwiteit van adolessente.

\section{Erkenning \\ Mededingende belange}

Die outeur verklaar dat hy geen finansiële of persoonlike verbintenis het met enige party wat hom nadelig kon beïnvloed het in die skryf van hierdie artikel nie.

\section{Literatuurverwysings}

Berenson, A.B., Helen Wu, Z., Bretkopf, C.M. \& Newman, J., 2006, 'The relationship between source of sexual information and sexual behavior among female adolescents', Contraception 73, 274-278. http://dx.doi.org/10.1016/j. contraception.2005.08.014, PMid:16472570

Berkowitz, C.D., 2005, 'The need for a developmental approach to adolescent decision-making', American Journal of Bioethics 5(5), 77-76. http://dx.doi. org/10.1080/15265160500246350, PMid:16179325

Bleakley, A., Hennessy, M., Fishbein, M. \& Jordan, A., 2009, 'How sources of sexual information relate to adolescents' belief about sex', American Health Behavio 33(1), 37-48.

Bornman, M.J., 2011, 'Adolessente se geloofsoortuiging en etiese besluitnemingsraamwerk met betrekking tot seksuele aktiwiteit: ' $n$ Christelik-etiese studie', MA verhandeling, Fakulteit Teologie, Noordwes-Universiteit.

Brill, E.H., 1979, The Christian moral vision, Seabury Press, New York.

Coetzee, J., 2002, 'The perceptions of morality of secondary school learners: A crosscultural study', MA dessirtation, Faculty of Health Sciences, University of the Free State.

Cohen, M., Chen, Y. \& Fitzgerald, E., 2008, 'Effects of a peer-led media literacy curriculum on adolescents' knowledge and attitudes toward sexual behavio and media portrayals of sex', Health Communication 23, 462-472. http://dx.doi. org/10.1080/10410230802342135, PMid:18850393

Collins, K., 1999, Participatory research: A primer, Prentice Hall, Cape Town.

Cooksey, E. \& Dooms, T., 2009, 'The role of religion in the sexual lives of teens', in S. Collins-Mayo \& P. Dandelion (eds.), Religion and Youth, p. 278, Ashgate, Surrey.
Denzin, N.K. \& Lincoln, Y.S., 2008, Strategies of qualitative inquiry, 3rd edn., Sage, Los Angeles.

Epstein, M. \& Ward, L.M., 2008, “"Always use protection": Communication boys receive about sex from parents, peers and the media', Journal of Youth Adolescence 37 113-126. http://dx.doi.org/10.1007/s10964-007-9187-1

Francis, S.A., 2007, 'Implications of public and private aspects of religiosity for the sexual decisions of black \& white adolescents', Journal of Youth Ministry $5(2)$ 15-31.

Goggin, K., Malcarne, V.L., Murray, T.S., Metcalf, K.A. \& Wallston, K.A., 2007, 'Do religious and control cognitions predict risky behavior? II Development and validation of the sexual risk behavior-related God locus of control scale for adolescents', Cognitive Therapy Research 31, 123-139. http://dx.doi.org/10.1007/ s10608-006-9090-1, http://dx.doi.org/10.1007/s10608-006-9091-0

Gorman, G.E. \& Clayton, P., 2005, Qualitative research for the information professional: A practical handbook, 2nd edn., Facet Publishing, London.

Greathead, E., Devenish, C. \& Funnell, G., 2008, Responsible teenage sexuality: A manual for teachers, youth leaders and health professionals, Van Schaik, Pretoria. PMid:18816909

Hardy, S.A. \& Raffaelli, M., 2003, 'Adolescent religiosity and sexuality: An investigation of reciprocal influences', Journal of Adolescence 26, 731-739. http://dx.doi. org/10.1016/j.adolescence.2003.09.003, PMid:14643743

Hetsroni, A., 2008, “'Dependency and adolescents" perceived usefulness of information on sexuality: A cross-cultural comparison of interpersonal sources professional sources and the mass media', Communication Reports 21(1), 14-32. http://dx.doi.org/10.1080/08934210802019330

Jason, L.A., Keys, C.B., Suarez-Balcazar, Y., Taylor, R.R. \& Davis, M.I., 2004, Participatory community research: Theories and methods in action, American Psychological Association, Washington. http://dx.doi.org/10.1037/10726-000, PMCid:1747892

Kemp, E., 2001, 'Observing practice as participant observation - linking theory to practice', Social Work Education 20(5), 527-538. http://dx.doi. theory to practice', Social Work
org/10.1080/02615470120072823

Kohlberg, L. 1976, 'Moral stages and moralization: The cognitive-developmental approach', in T. Lickona (ed.), Moral development and behavior: Theory, research and social issues, pp. 31-53, Holt, Rinehart \& Winston, New York.

Larney, T. \& Lotter, G.A., 2005, 'Ouers se rol in die oordrag van etiese en morele waardes', Koers 70(4), 661-683. http://dx.doi.org/10.4102/koers.v70i4.287

Louw, D.A., Van Ede, D.M. \& Louw, A.E., 1998, Menslike ontwikkeling, 3rd edn, Kagiso Tersiêr, Kaapstad.

Mash, R., 2006, 'Church teaching and the views of youth on sexual practices: A study amongst Anglican youth of the Cape Town Diocese aged 12-19', M.Th dissertation, Faculty of Theology, University of Stellenbosch

Meier, A.M., 2003, 'Adolescents transition to first intercourse, religiosity and attitudes about sex', Social Forces 81(3), 1031-1052. http://dx.doi.org/10.1353/ sof.2003.0039

Odimegwu, C., 2003, 'Influence of religion on adolescent sexual attitudes and behaviour among Nigerian university students: Affiliation or commitment?', African Journa for Reproductive Health 9(2), 125-140. http://dx.doi.org/10.2307/3583469

Orapeleng, G.M., 2002, 'Pre-marital sex among Seventh Day Adventist youth in Botswana and possibilities for preventative action', M.Th dissertation, Faculty of Theology, University of South Africa.

Pattee, A., 2006, 'The secret source: Sexually explicit young adult literature as an information source', Young Adult Library Services Winter, 30-38.

Piaget, J., 1971, Biology and knowledge: An essay on the relations between organic regulations and cognitive processes, Edinburgh University Press, Edinburg.

Price Tangney, J., 2003, 'Self-relevant emotions', in M.R. Leary \& J. Price Tangney (eds.), Handbook of self and identity, pp. 384-400, The Guilford Press, New York.

Prins, J.M.G., 2001, 'Intensionele morele vorming: Noodsaaklik in kerklike jeugbediening', Praktiese Teologie in S.A. 16(1), 105-119.

Reason, P., 1998, 'Three approaches to participative inquiry', in N.K. Denzin \& Y.S. Lincoln (eds.), Strategies of qualitative inquiry, p. 346, Sage, London.

Robson, C., 2002, Real world research: A resource for social scientists and practitioner researchers, 2nd edn., Blackwell, Madden Mass.

Saelen, C. \& Markovits, H., 2008, 'Adolescents' emotion attributions and expectations of behaviour in situations involving moral conflict', Journal of Experimental Child Psychology 100, 53-76. http://dx.doi.org/10.1016/j.jecp.2008.01.002, PMid:18313068

Simons, L.G., Burt, C.H. \& Peterson, F.R., 2009, 'The effect of religion on risky sexual behavior among college students', Deviant Behavior 30, 467-485. http://dx.doi. org/10.1080/01639620802296279

Singer, M.S., 1999, 'The role of concern for others and moral intensity in adolescents ethicality judgments', The Journal of Genetic Psychology 160(2), 155-166. http:// dx.doi.org/10.1080/00221329909595389

Slavin, R.E., 2006, Educational psychology: Theory and practice, 8th edn. Allyn \& Bacon, Boston.

Steyn, R.S. \& Lotter, G.A., 2006, 'Veranderende tendense en die implikasies vir jongmensverhoudings', Koers 71(2, 3, 4), 535-555.

Swart, B., 2004, 'Die verband tussen stadium van morele ontwikkeling en lokus van kontrole by'n groep Afrikaanssprekende adolessente', MA verhandeling, Fakulteit Teologie, Universiteit van Stellenbosch.

Vorster, J.M., 2004, Ethical perspectives on human rights, Potchefstroom Theological Publications, Potchefstroom.

Winner, L.F., 2005, 'Sex in the body of Christ', Christianity Today, 13 May, pp. 29-33.

Wright, C., 2003, God and morality, Oxford University Press, New York. 